\title{
Mineralogical and Heavy Metal Assessment of Iraqi Soils from Urban and Rural Areas
}

\author{
Nidal Al Derzi* and Amel Muhsen Naji** \\ * Chemistry Division, Department of Applied Sciences, University of Technology, Baghdad-Iraq. \\ ** Dijlah College, Baghdad-Iraq.
}

\begin{abstract}
The concentrations of $\mathrm{Cu}, \mathrm{Ni}, \mathrm{Pb}, \mathrm{Zn}$, and $\mathrm{Cr}$ in top soils $(0-15 \mathrm{~cm})$ from urbanized and rural areas of Iraq were measured by X-ray fluorescence analysis (XRF). The results revealed that soil samples located in urban areas had higher metal contents than did soil samples from rural areas. This was probably due to local pollution from increased population and other industrial sources.

The comparison with the soil quality guidelines showed that metal concentrations in all the studied locations are lower than the permissible levels admitted by the World Health Organization (WHO).

The mineralogical composition of the top soils, identified by X-ray diffraction (XRD), was predominantly Quartz, Calcite and minor minerals such as Dolomite, Feldspar and clay minerals. Total clay minerals in the soil samples, ranged from 3-10\%, were found to be dominated by Montmorillonite, Kaolinite and Feldspar. The highest clay content was observed in Diala soils near the river Tigris.
\end{abstract}

Keywords: Heavy metals, X-ray fluorescence, pollution, urban soils.

\section{Introduction}

In recent years a great deal of concern has been expressed over problems of soil contaminations with heavy metals. These metals can accumulate in plants and animals, eventually making their way to humans through food chain [1-3]. Soil samples present an excellent media to monitor heavy metal pollution because heavy metals are usually deposited in topsoil. Furthermore soils not only serve as sources for certain metals but can also function as sinks for metal contaminates [4,5]. Studies of heavy metals in ecosystems have indicated that many urban areas contain enormous high concentrations of these elements. Therefore, analysis of heavy metals in soil offer an ideal means to monitor not only the pollution of soil itself, but also to quantity the overall environment as reflected in soil $[6,7]$.

The main factors known to influence the level of pollution in soil samples are traffic, industry and weathered materials and the transportation of various elements by rivers and water channels that causes great contamination to the surrounding areas. Generally, the distribution of heavy metals is influences by the nature of parent materials, climate and their relative mobility depending on soil parameter, such as mineralogy and classification of soil [8].

The Wet Chemical Analysis test for soils is currently applied to investigate the concentration levels of heavy metals in soils. However this method has many steps, including the extraction procedure with a strong acid solution. It is also quite complex and expensive, and takes a long time. Accordingly, since a rapid and appropriate analysis is critical for a successfully conducting the operation within a constructed time schedule, it is necessary to have an alternative advanced method to overcome these shortcomings of the test for soils [9].

The X-ray method is a non-destructive analytical technique, allowing both qualitative and quantitative analysis of metal species and compounds in soils. The mechanism of X-ray analysis can be briefly explained as follows: (1) An incident x-ray photon produced from the $\mathrm{x}$-ray tube excitation source creating an inner shell vacancy in which an electron leaves the inner shell; (2) when an atom relaxes to the ground state, an outer shell electron falls to make up for the inner shell vacancy; (3) then photons are given off with an energy in the $\mathrm{x}$-ray region of the electromagneticspectrum, that is equivalent to the energy difference 
between the two shells (4). The energy level and intensity of these emitted x-rays identify the elements and their concentrations respectively [10].

With a view to understand the heavy metal contamination in soil, the present study was carried out on soil samples in urban areas (diala, mandali, and Baghdad) and two unurbane districts in the western desert of Iraq.

In this study, x-ray diffractometry and $\mathrm{x}$-ray fluorescence spectrometry were used to investigate the mineral composition and heavy metal concentrations of the soil samples. The results were compared with data obtained from the admitted regulation levels to investigate the source of contamination.

\section{Experimental Sample preparation}

The surface soils $(0-15 \mathrm{~cm})$ were collected from four urbanized Iraqi areas (Taji, Mandili, Diala, Baghdad) and two from un-urbanized areas in the western desert. (Locations are shown in Figure1, from Google Earth). Four samples were collected over a total of approximately $10 \mathrm{~km}^{2}$ from each area and kept in PVC packages. Back in the laboratory, soil samples were dried at $500 \mathrm{C}$ and large rock and organic debris were removed before sieving. The samples were then ground to a fine powder $(<125 \mu \mathrm{m})$ in an agate mortar. The pulverized samples were newly dried at $60^{\circ} \mathrm{C}$ until obtaining a constant weight.

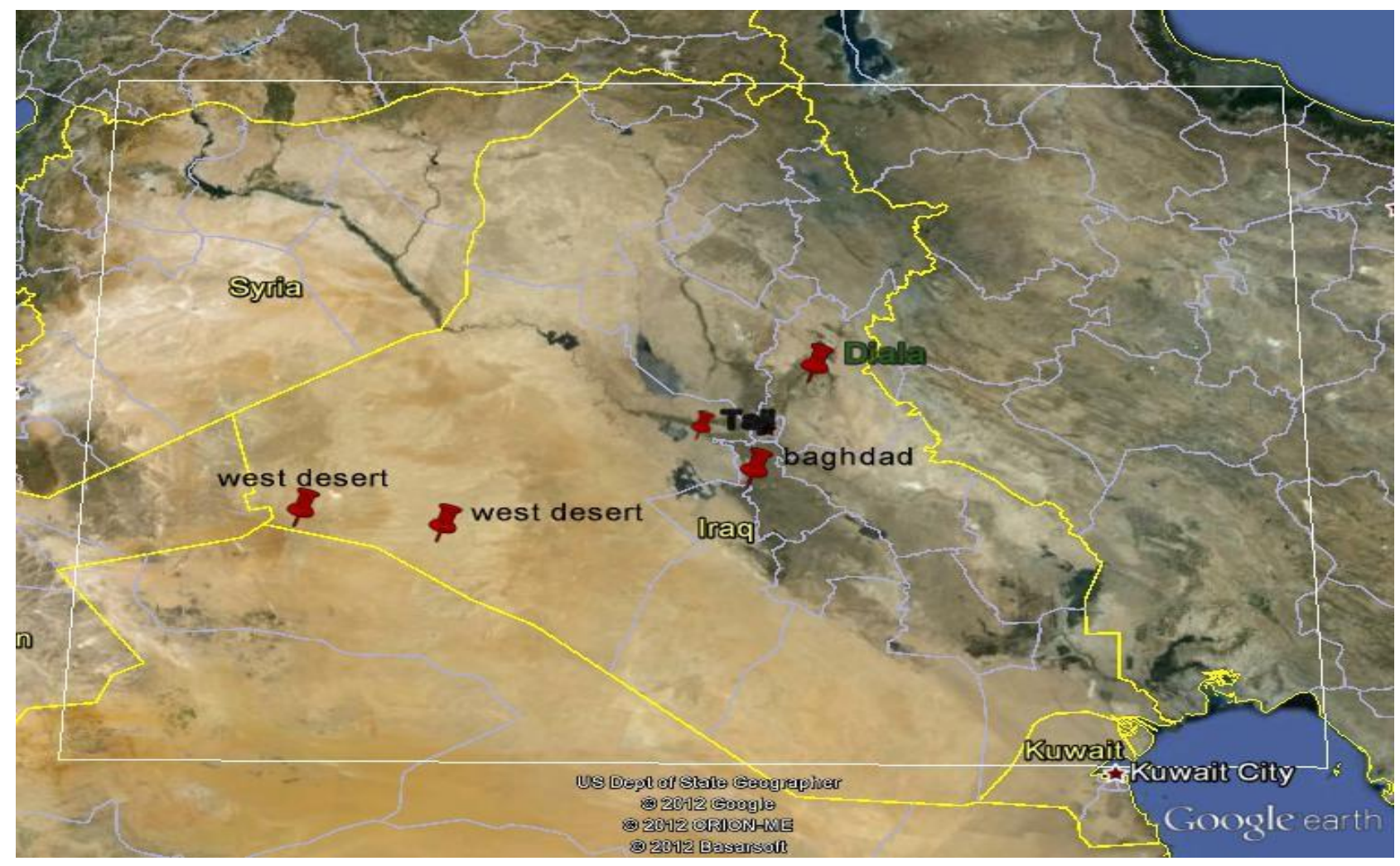

Fig. (1) Geographic areas included into the study.

\section{Mineral Identification}

Mineral identification is important, as they may influence the behavior and properties of soil materials, such as the cation exchange capacity, surface area and retention [11]

The X-ray diffraction (XRD) was undertaken to investigate qualitatively the minerals in the soil samples. Data were collected on a Schimatzu X-ray diffractometerusing $\mathrm{Cu} \mathrm{K} \alpha$ radiation. The samples were repeatedly scanned from 2 to $70^{0}$ $2 \theta$ at a speed of $2^{0} 2 \theta$ per minute.

Clay minerals in relatively low concentration can give weak XRD peaks and difficult to be identified. To better identify the clay minerals in the soil samples, extraction have been made as follows:-

$50 \mathrm{~g}$ of soil was placed in a $250 \mathrm{ml}$ beaker. About $50 \mathrm{ml}$ of $(25 \%)$ acetic acid was then added to it and was mixed thoroughly using a mechanical move the calcite, $\left(\mathrm{CaCO}_{3}\right)$, 
dolomite, $\mathrm{CaMg}\left(\mathrm{CO}_{3}\right)_{2}$ and some of the Gypsum, $\mathrm{CaSO}_{4}$ minerals [12]

$\mathrm{CaCO}_{3 \text { (calcite) }}+2 \mathrm{H}^{+} \rightarrow \mathrm{Ca}^{2+}+\mathrm{CO}_{2} \uparrow+\mathrm{H}_{2} \mathrm{O}$

$\mathrm{MgCa}\left(\mathrm{CO}_{3}\right)_{2}+4 \mathrm{H}^{+} \rightarrow \mathrm{Ca}^{2+}+\mathrm{Mg}^{2+}+2 \mathrm{CO}_{2} \uparrow$ $+2 \mathrm{H}_{2} \mathrm{O}$

The upper suspension was pipetted, placed on a watch glass and air dried. The approximate percentage of clay minerals were calculated as follows:-

$\mathrm{Wt} \%$ of clay minerals $=$ $\frac{\text { weight of dried suspension }}{\text { Total weight }} \times 100$

Minerals were identified qualitatively using peak positions in the X-ray diffraction pattern (diffractogram), using Bragg's law which is written as:- $n \lambda=2 \mathrm{~d} \sin \theta$, where, $\lambda$ is the wavelength of the X-ray beam, $\theta$ is the diffraction angle, $\mathrm{d}$ is the distance between two adjacent diffraction lattice planes, and, $n$ is an integer stands for the order of diffraction [13]. To verify the identification, the measured $\mathrm{d}$-spacings and intensities obtained from the recorded X-ray pattern were compared to the data of the powder diffraction standards (ASTM).

All samples were ground to a fine powder and pressed on a special holder for X-ray analysis.

\section{Elemental Analysis}

$\mathrm{X}$-ray fluorescence analysis was performed on Schimatzu spectrometer containing the total reflection unit and the excitation source equipped with $\mathrm{W}$-anod $\mathrm{x}$-ray tube with a berellium window performed at $1.5 \mathrm{kw}(50 \mathrm{KV}$, $30 \mathrm{~mA}$ ). The fluorescent X-rays emitted by the material sample are directed into a diffraction grating monochromator. The metal concentrations were estimated by corellating $\mathrm{X}$-ray intensities with the certificate standard values.

All samples were ground to a very fine powder $(<50 \mu \mathrm{m})$ using a grinding mill and mixed with boric acid as a binder in proportions $(4: 1)$. The mixture was pressed to the pellets of $25 \mathrm{~mm}$ diameter and $4-5 \mathrm{~mm}$ diameter height under a hydraulic pressure. All samples were measured using the same experimental conditions.

\section{Results and Discussions Mineral Identification}

Each material was first examined in its natural state. The major minerals observed in XRD analysis of the soil samples are presented in Fig.(2). The reflections (3.34A, 3.04A), reveals the presence of Quartz $\left(\mathrm{SiO}_{2}\right)$ and Calcite $\left(\mathrm{CaCO}_{3}\right)$ as major constituents with little amounts of Dolomite, Feldspar, and clay minerals.

The approximate amount of clay minerals after extraction ranges from $2-10 \%$ as presented in Table (1).

The major clay minerals observed in XRD analysis of the extracted soil samples are presented in Figure3. Results show that clay minerals in the soil samples are dominated by montmorilonite, kaolinite, and feldspar minerals. However, there is aslight variation among the type of clay minerals, depending on localities. Kaolinite is the major clay mineral in the western desert, whereas the highest percentage of montmorillonite has been found in Diala district near the river Tigris. This might be due to the transportation and precipitation of small size particulates from the river[14,15]. The relatively high sand (Quartz) content observed in Iraqi soils might be due to the severe climate conditions and dust storms. The carbonate and Gypsumminerals may be the erosion products of the northern Iraqi hills and mountains[16,17]. 


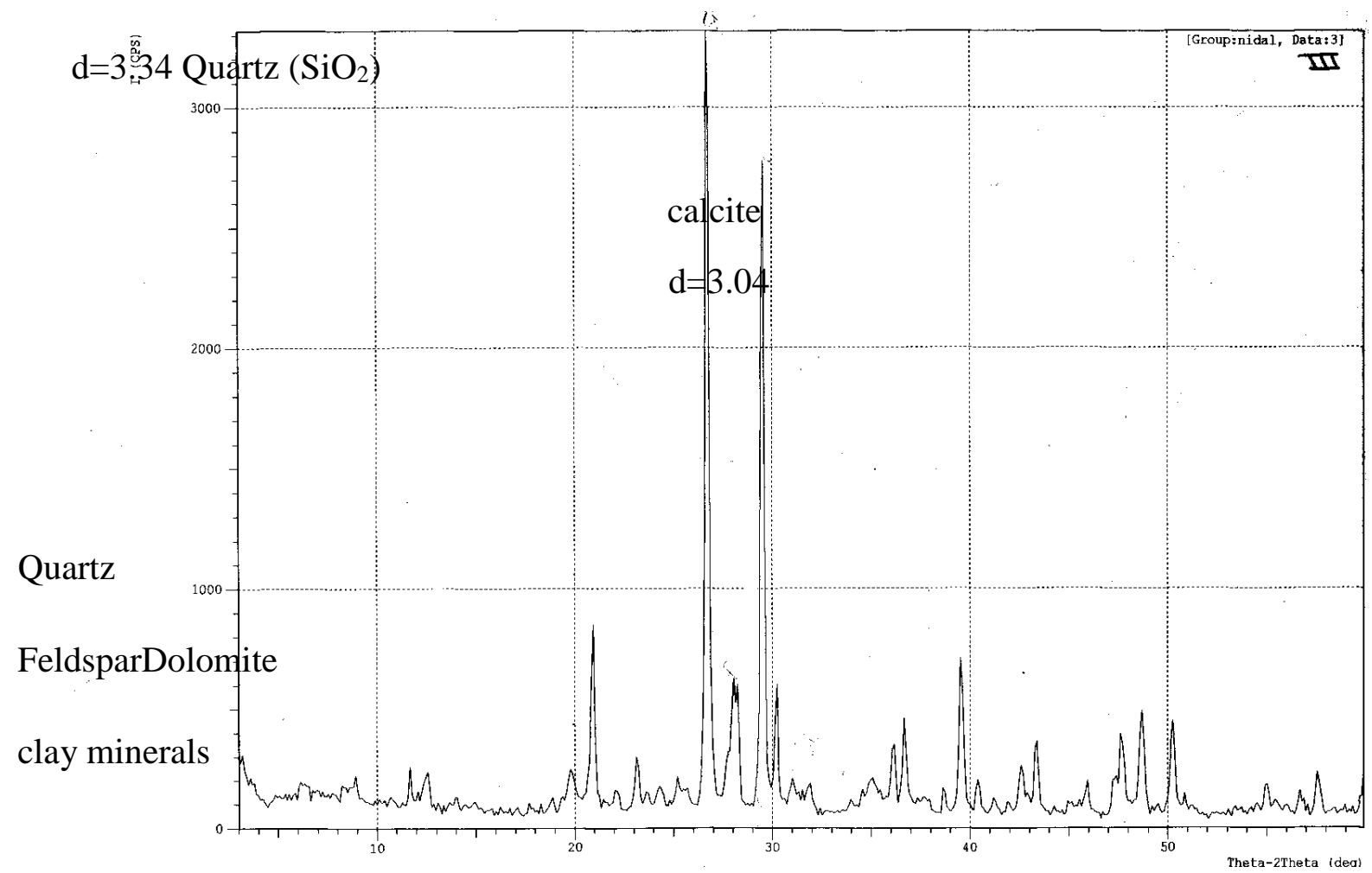

Fig.(2) X-ray diffractogram for a representative soil sample fromdifferent Iraqi localities.

Table (1)

The calculated amounts of clay minerals in different Iraqi locations.

\begin{tabular}{|c|c|c|c|c|c|c|c|c|c|c|c|}
\hline \multicolumn{8}{|c|}{ Urban districts } & \multicolumn{4}{|c|}{ Un-urban districts } \\
\hline \multicolumn{2}{|c|}{$\begin{array}{c}A l-T a j i \\
(T)\end{array}$} & \multicolumn{2}{|c|}{$\begin{array}{l}\text { Mandili } \\
\qquad(M)\end{array}$} & \multicolumn{2}{|c|}{$\begin{array}{l}\text { Diala } \\
\text { (D) }\end{array}$} & \multicolumn{2}{|c|}{$\begin{array}{c}\text { Baghdad } \\
\text { (B) }\end{array}$} & \multicolumn{2}{|c|}{$\begin{array}{c}\text { West desert } \\
\text { (1) } \\
\text { WD1 }\end{array}$} & \multicolumn{2}{|c|}{$\begin{array}{c}\text { West desert } \\
\text { (2) } \\
\text { WD2 }\end{array}$} \\
\hline $\begin{array}{c}\text { Sample } \\
\text { No. }\end{array}$ & $\%$ & $\begin{array}{c}\text { Sample } \\
\text { No. }\end{array}$ & $\begin{array}{c}\% \\
\text { clay }\end{array}$ & $\begin{array}{c}\text { Sample } \\
\text { No. }\end{array}$ & $\begin{array}{c}\% \\
\text { clay }\end{array}$ & $\begin{array}{c}\text { Sample } \\
\text { No. }\end{array}$ & $\begin{array}{c}\% \\
\text { clay }\end{array}$ & $\begin{array}{c}\text { Sample } \\
\text { No. }\end{array}$ & $\begin{array}{c}\% \\
\text { clay }\end{array}$ & $\begin{array}{c}\text { Sample } \\
\text { No. }\end{array}$ & $\%$ \\
\hline $\mathbf{T}_{1}$ & 7 & $\mathbf{M}_{1}$ & 7 & $\mathbf{D}_{1}$ & 10 & $\mathbf{B}_{1}$ & 6 & WD1-1 & 3 & WD2-1 & 6 \\
\hline $\mathbf{T}_{2}$ & 6 & $\mathbf{M}_{2}$ & 8 & $\mathbf{D}_{2}$ & 8 & $\mathbf{B}_{2}$ & 5 & WD1-2 & 4 & WD2-2 & 5 \\
\hline $\mathbf{T}_{\mathbf{3}}$ & 8 & $\mathbf{M}_{3}$ & 9 & $\mathbf{D}_{3}$ & 11 & $\mathbf{B}_{3}$ & 7 & WD1-3 & 6 & WD2-3 & 5 \\
\hline $\mathbf{T}_{4}$ & 7 & $\mathrm{M}_{4}$ & 8 & $\mathbf{D}_{4}$ & 11 & $\mathbf{B}_{4}$ & 6 & WD1-4 & 3 & WD2-4 & 4 \\
\hline
\end{tabular}




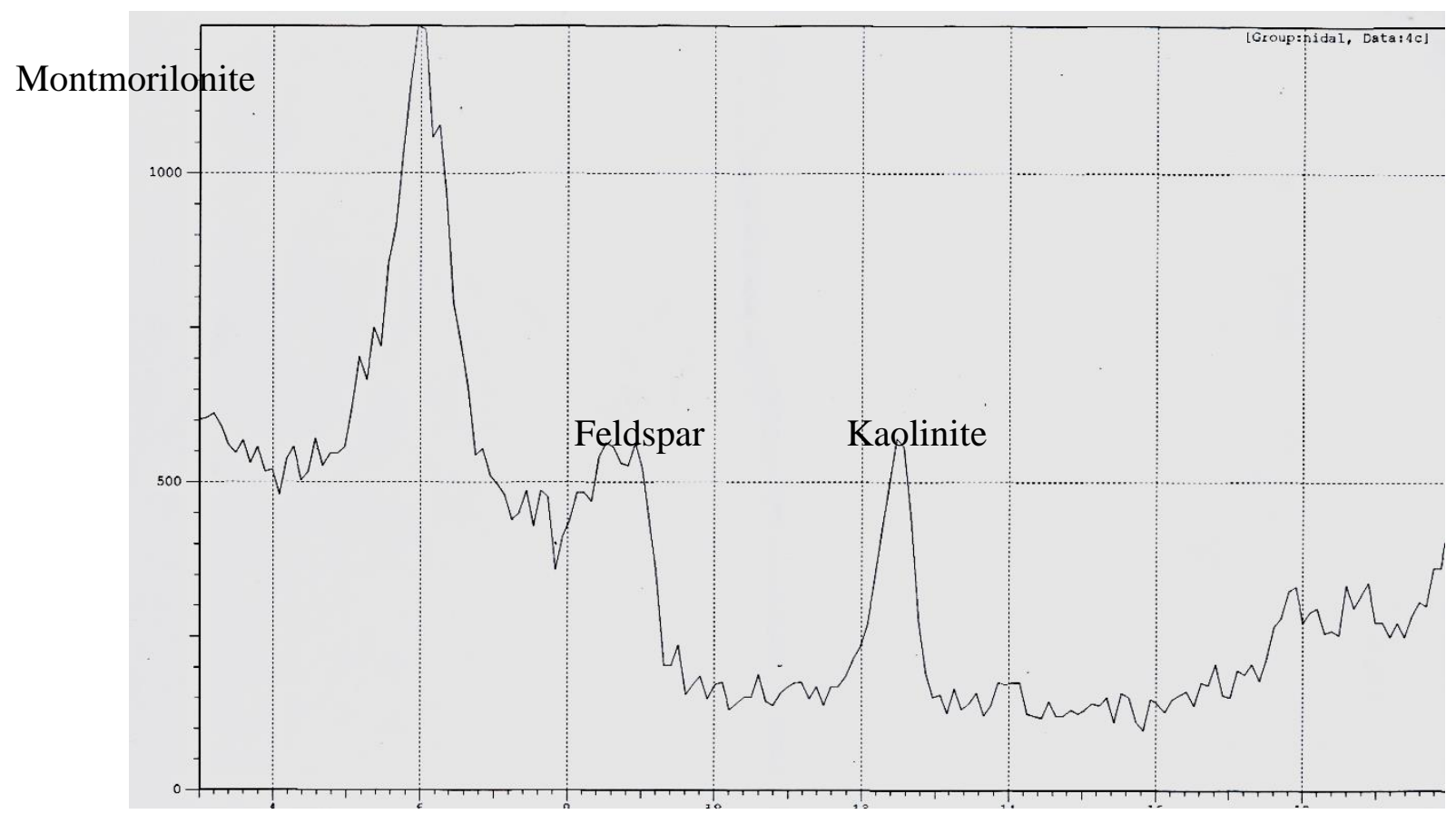

Fig.(3) X-ray diffractogram for extracted clay minerals in Diala district.

\section{Elemental analysis}

The concentration of six heavy metals $(\mathrm{Cd}$, $\mathrm{Cu}, \mathrm{Ni}, \mathrm{Pb}, \mathrm{Zn}$, and $\mathrm{Cr}$ ) was identified and quantified by using $\mathrm{X}$-ray fluorescence spectrometry (XRF) in six locations situated in urban and un-urbanized areas in Iraq (Tables $(2,3)$ ).

Due to the lack of an official Iraqi guidelines for healthy concentrations of metalsin urban soils, metal concentrations are compared with soil quality standards admitted by the World Health Organization WHO, (Table (4)). All the concentrations of identified soil metals were found to be below the permissible level. The highest metal contents were recorded from urban areas and the lowest from un-urbanized areas, Fig.(4).

The concentration ranges of heavy elements in urban areas were: $\mathrm{Cu}$ varied from 25 to $\left.60 \mathrm{mg} \cdot \mathrm{kg}^{-1} \mathrm{mg} \cdot \mathrm{kg}^{-1}\right)$, $\mathrm{Ni}$ from 5 to $18 \mathrm{mg} \cdot \mathrm{kg}^{-1}$ (mean: $10 \pm 3 \mathrm{mg} \cdot \mathrm{kg}^{-1}$ ), $\mathrm{Pb}$ from 36 to 120 , (mean:76 \pm 2 ), $\mathrm{Zn}$ from 55 to 95 , (mean: $76 \pm 2$ ). These are significantly higher than the corresponding values in un-urbanized areas.

The highest metal concentrations were recorded in Baghdad urban districts. This can be caused by pollution from variety of sources, most importantly; the increased population growth, economic development and rapid urbanization [18].
The mean concentrations of $\mathrm{Zn}$ and $\mathrm{Pb}$ in soils from urban areas were higher by 3 and 3.7 times the values in un-urbanized areas. This might be due that these metals had similar pollution sources. The most usual sources are traffic (i.e. vehicular emission and other industrial sources) and thermoelectric centers [19]. 
Table (2)

Heavy metal concentrations $\left(\mathrm{mg}_{\mathrm{kg}} \mathrm{k}^{-1}\right)$ in soil samples from urban areas.

\begin{tabular}{|c|c|c|c|c|c|c|c|}
\hline Urban districts & Sample No. & $C d$ & $\mathrm{Cu}$ & $\mathrm{Ni}$ & $\mathrm{Pb}$ & $Z n$ & $\mathrm{Cr}$ \\
\hline \multirow{4}{*}{ Al Taji } & $\mathbf{T}_{1}$ & $<5$ & 25 & 8 & 36 & 82 & 7 \\
\hline & $\mathbf{T}_{2}$ & - & 27 & 7 & 32 & 75 & 9 \\
\hline & $\mathbf{T}_{\mathbf{3}}$ & - & 23 & 9 & 39 & 84 & 5 \\
\hline & $\mathbf{T}_{4}$ & - & 25 & 8 & 37 & 87 & 7 \\
\hline \multirow{4}{*}{ Mandali } & $\overline{\mathbf{M}_{1}}$ & $<<5$ & 32 & $\overline{10}$ & $\overline{55}$ & $\overline{255}$ & $<<5$ \\
\hline & $\mathbf{M}_{2}$ & - & 29 & 9 & 60 & 52 & - \\
\hline & $\mathbf{M}_{3}$ & - & 34 & 11 & 53 & 54 & - \\
\hline & $\mathrm{M}_{4}$ & - & 33 & 10 & 52 & 59 & - \\
\hline \multirow{4}{*}{ Diala } & $\overline{D_{1}}$ & $<<5$ & 38 & 5 & 63 & 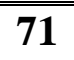 & $<<5$ \\
\hline & $\mathbf{D}_{2}$ & - & 40 & 7 & 65 & 70 & - \\
\hline & $\mathbf{D}_{3}$ & - & 35 & 6 & 58 & 72 & - \\
\hline & $\mathbf{D}_{4}$ & - & 39 & 7 & 66 & 72 & - \\
\hline \multirow{4}{*}{ Baghdad } & $\overline{\mathbf{B}_{1}}$ & $<<5$ & 60 & 18 & 120 & 95 & $\overline{8}$ \\
\hline & $\mathbf{B}_{2}$ & - & 58 & 16 & 116 & 90 & 7 \\
\hline & $\mathbf{B}_{3}$ & - & 65 & 21 & 125 & 96 & 9 \\
\hline & $\mathbf{B}_{4}$ & - & 57 & 17 & 119 & 92 & 8 \\
\hline
\end{tabular}

Table (3)

Heavy metal concentrations (mg. $\left.\mathrm{kg}^{-1}\right)$ in soil samples from un-urban areas.

\begin{tabular}{|l|c|c||c||c||c|c||c||}
\hline Un-urban districts & Sample No & $C d$ & $C u$ & $N i$ & $P b$ & $Z n$ & $C r$ \\
\hline \hline \multirow{5}{*}{ Western desert (1) } & WD1-1 & $<5$ & 15 & $<5$ & 22 & 33 & $<5$ \\
& WD1-2 & - & 14 & - & 19 & 32 & - \\
& WD1-3 & - & 15 & - & 25 & 33 & - \\
& WD1-4 & - & 16 & - & 22 & 34 & - \\
\hline \hline \multirow{5}{*}{ Western desert (2) } & WD2-1 & $<5$ & 12 & $<5$ & 15 & 25 & $<5$ \\
& WD2-2 & - & 10 & - & 14 & 26 & - \\
& WD2-3 & - & 11 & - & 16 & 26 & - \\
& WD2-4 & - & 15 & - & 15 & 23 & - \\
\hline
\end{tabular}

The highest lead $(\mathrm{Pb})$ concentrations in top soils were recorded in Baghdad urbanized areas. One factor contributing to the greater concentration of lead $(\mathrm{Pb})$ in the top soils along with the probable pollution was the metal limited mobility.

The highest $\mathrm{Pb}$ concentrationsrecorded in Baghdad area was probably due to local pollusion by industrial dust and contributions from the wind from adjacent areas with industries and transportation activities [20]. 


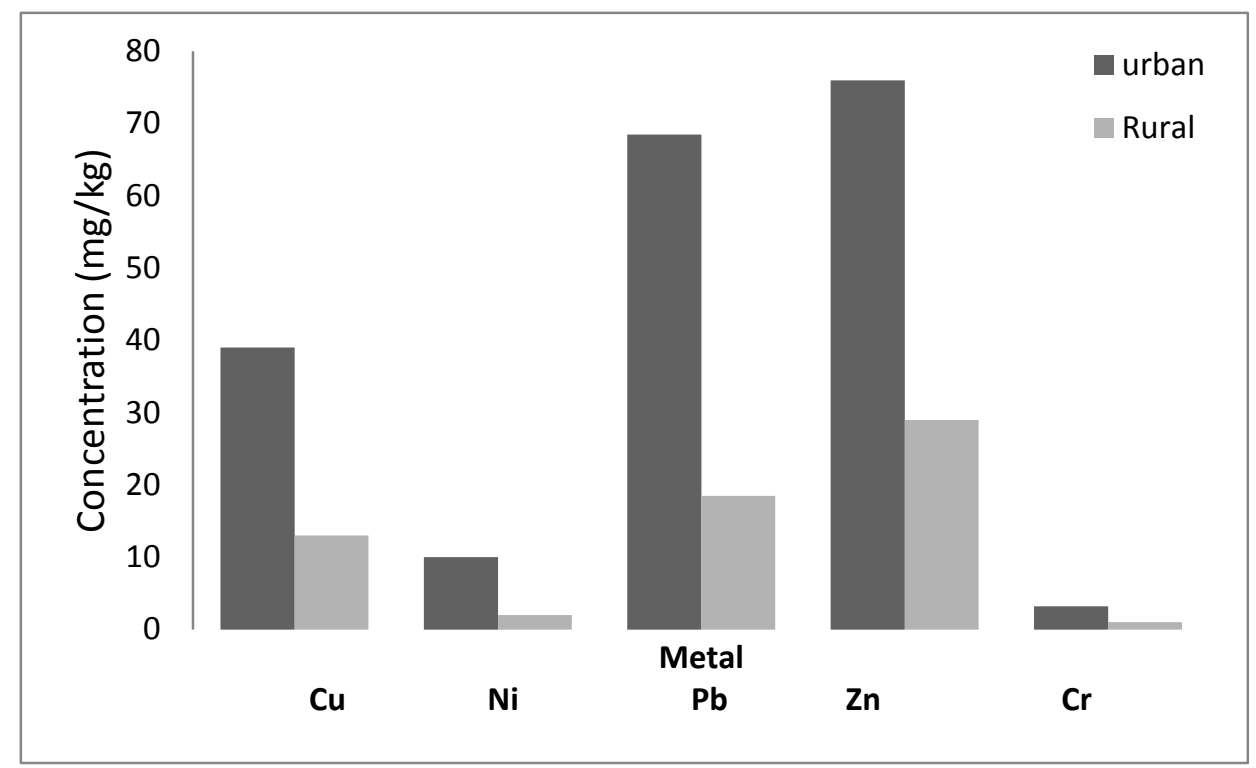

Fig. (4) Mean values of metal concentrations in the soil samples.

Table (4)

Maximum concentrations admitted by WHO.

\begin{tabular}{|c||c|}
\hline Element & $\begin{array}{c}\text { Permitted values } \\
\left(\text { mg.kg }^{-1}\right)\end{array}$ \\
\hline \hline $\mathrm{Cd}$ & $1-3$ \\
\hline $\mathrm{Cu}$ & $50-140$ \\
\hline $\mathrm{Ni}$ & $30-75$ \\
\hline $\mathrm{Pb}$ & $50-300$ \\
\hline \hline $\mathrm{Zn}$ & $150-300$ \\
\hline \hline $\mathrm{Cr}$ & $1-5$ \\
\hline
\end{tabular}

\section{Conclusion}

The concentrations of heavy metals in the topsoil samples $(0-15 \mathrm{~cm})$ collected from urban and un-urbanized areas were below the target concentration levels reported by WHO. However, soil samples from urbanized areas show higher metal concentrations than the corresponding concentrations in un-urbanizes areas. This indicates that urban areas have been affected by pollution from hazardous waste, leading to accumulation of heavy metals. In terms of mean concentration values, the order of metals present in the soil samples from highest to lowest was:

\section{$\mathrm{Zn}>\mathrm{Pb}>\mathrm{Cu}>\mathrm{Ni}>\mathrm{Cr}$}

Increased $\mathrm{Pb}$ levels in surface soils from Baghdad area can be caused by pollution from transportation activities, vehicle emissions and pollution from transportation activities, vehicle emissions and industrial waste. The mineralogical composition of the top soil samples identified by X-ray diffraction was predominantly Quartz, Calcite, Dolomite and minor minerals such as Feldspar and clay minerals. The major clay minerals were identified as Montmorillonite, Kaolinite and feldspar. The relatively high sand (Quartz) content observed in the soil samples may be due to the severe climate conditions, dust storms, and lower rainfall.

We suggest that severe climatic conditions, dust storms, local emissions and uncontrolled industrial work are the major factors leading to increased accumulation of heavy metals.

\section{Acknowledgment}

We thank the Directorate of the Geological Survey and Mineral Investigation / Ministry of Industry for technical assistance.

\section{References}

[1]. Govil P.K, Reddy G.L.N and Krishne A.K; Contamination of soil due to heavy metals in Patanchera industrial development area; Andra Pradesh, India, Environmental Geology, 41, 461-469, 2001.

[2].Romic M and Romic D; Heavy metal distribution in agricultural top-soils in urban area; Environmental Geology; 43, 795-805, 2003.

[3].Lu.S.G, Bai. S.Q; Contamination and potential mobility assessment of heavy metals in urban soils of Hangzhou, China; Environ. Earth Sci.; 60, 1481, 2010. 
[4].Krzyztof, Loska, Danutta, Wiechua \& Irena Korus; Metal contaminations of farming soils affected by industry; Environmental International; 30 (2), 159165, 2004.

[5].Ramona Carr, Chaosheng Zhang, Norman Moles, Maric Harder; Identification and mapping of heavy metal pollution in soils of a sport ground in Galway city, Ireland, using a portable XRF analysis and GIS; Environ Geochem Health;52, 45-52, 2008.

[6]. Arantzazu U, Vega M \& Angul E; Deriving ecological risk based soil qualityvaluesin the Banquecountry; The Science of the Total Environment; 247, 279-284, 2000.

[7].Nurra S, Fjer N.F, Chu X, Stuben D; The influence of different land uses on mineralogical and chemical composition and horizonation of urban soil profiles in China; China J.Soils Sediments ; 8 (1), 4-16, 2008.

[8].Zhang C; Environ Pollut.; Using multivariant analysis and GIS to identify pollutants and their spatial patterns in urban soils in Galway Ireland; 142(3), 501-511, 2006.

[9].Hettipathirana T.D; Simultaneous determination of trace level $\mathrm{Cr}, \mathrm{As}, \mathrm{Cd}, \mathrm{Pb}$ and major elements in low contaminated soils using borate fusion and energy dispersive X-ray fluorescence spectrometry with polarized excitation; Spectrochimica Acta, part B, 59,223-229, 2004.

[10]. Min Jang; Application of portable X-ray fluorescence (PXRF) for heavy metal analysis of soils in crop fields near abandoned mine sites; Environ Geochem Health; 32, 207-216, 2010.

[11]. Al Khashman, O.A; The investigation of metal concentrations in street dust samples in Aqaba city, Jordan; Environmental Geochemistry and Health; 29. 1-10, 2007.

[12]. Katherine Ozalas and Benjamin F.Hajek, $X$-ray diffraction analysis of thin clay films from dilute suspensions using glancing incidence diffraction; Clays and Clay Minerals; 44 (6), 811-817, 1996.

[13]. Oprea C, maslov O.D, Gustova M.V, Belov A.G, Szalanski P.J, Oprea I.A; Methods used in oil contamination research; Vacuum, 83, S 162-S165, 2009.
[14]. Katrina K, Davina R, Veronica C, Sharuslav R; Road-deposited sediments $(R D S)$, soil presipitation in Bratislava, Slovakia: compositional and spatial assessment of contamination; J. Soils Sediments; 9, 304-316, 2009.

[15]. Omar A, Al-Khashimi Reyad; Metal distribution in urban soil around steel industry beside Queen Alia Airport, Jordan; Environ Geochem Health; 31, 717-726, 2009.

[16]. Khashman O.A; Heavy metal distribution in dust, street dust and soil from the work place in Al-Karak Industrial Estate, Jordan; Atmospheric Environment; 38, 6803-6812, 2004.

[17]. Charlesworth SM, Lees JA; The distribution of heavy metals in deposited urban dusts and sediments; Environ Geochem Health; 21, 97-115, 1999.

[18]. Yuji A, Allison R, Tessa S, Emily F, Ryan T, Antonio L; Microscopic and molecular-scale assessment of soil lead contamination impacted by seasonal dove hunting activities; J. Soil Sediments; 11: 968-979, 2011.

[19]. Kutle A, Orescanin V, Obhoda J, Valkovic C ; Trace element distribution in geochemical environment of the Island $\mathrm{KrK}$ and its influence on the local population; Journal of Radioanalytical and Nuclear Chemistry; 259 (2),271-276, 2004.

[20]. Carreras H.A and Pignata M.L; Biomonitoring of heavy metals and air quality in Cordoba city, Argentina, using transplanted lichens; Environmental Pollution; 17, 71-87, 2002. 


\section{الخلاصة}

تم استخدام الأشعة السينية الوميضية (XRF) لتعيين

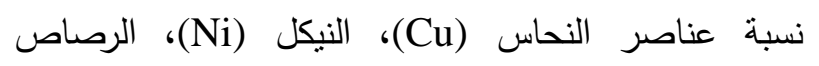

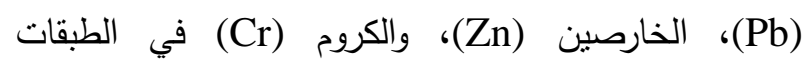

السطحية للتربة (10 سم) ومأخوذة من المناطق المأهولة

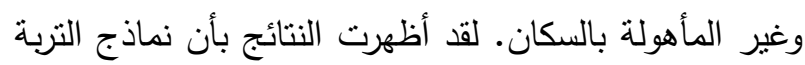

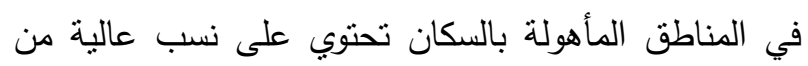
العناصر مقارنة بتلك المأخوذة من المناطق غير المأهولة، وقد يعزى ذلك الى التلوث المحلي الناتج من الزيادة السكانية

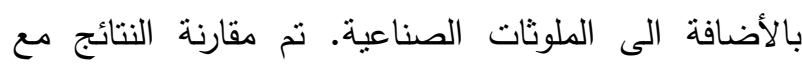
الحدود المسموح بها وتبين ان نسبة العناصر في كافة المناطق تحت الدراسة هي اقل من الحدود المسموح بها حسب منظمة الصحة العالمية (WHO). أظهرت نتائج التشخيص بواسطة حيود الأشعة السينية (XRD) بأن

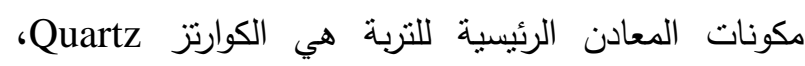
الكالسايت Calcite، ونسب اقل من معادن الدولومايت

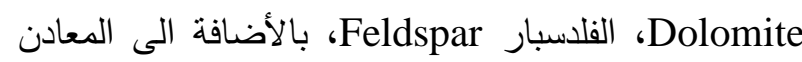

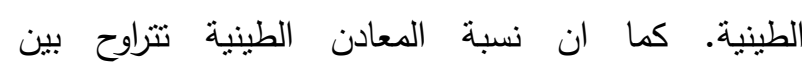

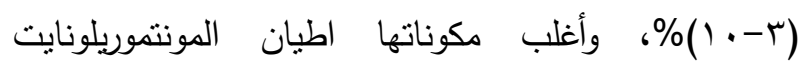
Montmorillonite Feldspar منطقة ديالى قرب نهر دجلة. 